\title{
Karyological Characters of the Fungi Causing Rice Sclerotiosis*
}

\author{
Kimiharu INAGAKI and Makoto MAKINO** \\ 稲垣公治・牧野 精**: イネを侵す菌核病菌の核学的観察*
}

In many literatures there are some confusions in the taxonomic distinction among the several species of Rhizoctonia and Sclerotium causing rice sclerotiosis. The main objective of the present karyological experiments is to contribute to the taxonomy of these fungi causing rice sclerotiosis.

The authors wish to express their gratitude to Prof. Y. Hashioka, Gifu University, for offering materials as well as for preparing this paper.

Materials and methods: Karyological characters of hyphalc ells were examined with 46 isolates of the difierent sclerotial fungi isolated mainly from rice plants. Namely, 12 isolates of Pellicularia sasakii (Shirai) S. Ito including 9 from Japan, 2 from Thailand and 1 from USA, 6 of Pellicularia filamentosa (Pat.) Rogers collected from Japan, 4 of Rhizoctonia oryzae Ryker et Gooch ${ }^{1)}$ from Thailand, 11 of Sclerotium oryzae-sativae Sawada including 6 from Japan, 1 from Laos and 4 from Thailand ( 3 of which were identified as this species according to the cultural characteristics), 3 of Sclerotium hydrophilum Saccardo from Japan and from Thailand, 4 of Sclerotium fumigatum Nakata and 1 of Sclerotium orizicola Nakata et Kawamura from Japan. Regarding the rice culm-rotinducing fungi, 2 isolates of Magnaporthe salvinii (Cattaneo) Krause et Webster ${ }^{2}$ ) and 3 of Curvularia irregulare (Cralley et Tullis) Hara from Japan were employed.

Each isolate was cultured on potato sucrose agar at $30 \mathrm{C}$, except Pellicularia filamentosa which was kept at $28 \mathrm{C}$. After $3 \sim 4$ days hyphal filaments were picked up on a cover glass which was coated previously with albumine. HCl-Giemsa method was applied as the nuclear staining of these fungi. Three hundred hyphal cells were observed for each isolate, though the culm-rot-inducing fungi were examined on $200 \sim 300$ cells.

Results and conclusion: The number of nuclei in a hyphal cell examined by means of Giemsa staining was almost similar to that by Feulgen staining previously reported.

A. Pellicularia sasakii: As shown in Table 1, the isolates examined were proved to contain 6 8 nuclei in each hyphal cell (Fig. 1). The results are in accordance with those reported by Fukano ${ }^{3)}$ and Hashioka $e a^{4}$ ). Isolate No. 7 collected in USA and No. 39 from Hyogo showed comparatively higher mean values than the others; No. 46 from Wakayama, No. 40 and No. 42 from Thailand showed somewhat lower mean values. The number of nuclei in each hyphal cell varies in such a wide range from 1 to 31 , though it does not seem to concern with locality.

B. Pellicularia filamentosa: Among 6 isolates derived from the different crops and tree, the

* Contribtions from the Phytopathological Laboratory, Faculty of Agriculture, Meijo University, Nagoya, Japan, No. 5. Read partly at the meeting of the Kansai Division, the Phytopathological

** Faculty of Agriculture, Meijo University, Nagoya, Japan 名城大学農学部

Society of Japan, held on Nov. 3, 1972 at Gifu, Japan5).

1) Ryker, T. C. and Gooch, F. S. (1938). Phytopathology $28: 233-246$.

2) Krause, R. A. and Webster, R. K. (1972). Mycologia 64: 103-114.

3) Fukano, H. (1932). Bull. Sci. Fac. Agr. Kyushu Univ. 5 : 117-136.

4) Hashioka, Y. and Makino, M. (1969). Res. Bull. Fac. Agr. Gifu Univ. 28: 51-63.

5) Inagaki, K. and Makino, M. (1973).Ann. Phytopath. Soc. Japan. $39: 155$ (Abst.).

6) Ui, T. and Saito, I. (1968). Mem. Fac. Agr. Hokkaido Univ. 6:359-363. 
Table 1. Number of nuclei per hyphal cell of the different fungi causing rice-sclerotiosis

\begin{tabular}{|c|c|c|c|c|}
\hline Fungus species & Isolate No. & Host & Mean value & Range \\
\hline Pellicularia sasakii & $\begin{array}{r}2 \\
7 \\
11 \\
16 \\
33 \\
34 \\
38 \\
39 \\
40 \\
42 \\
46 \\
53\end{array}$ & $\begin{array}{l}\text { Rice } \\
\text { do } \\
\text { do } \\
\text { do } \\
\text { do } \\
\text { do } \\
\text { do } \\
\text { do } \\
\text { do } \\
\text { do } \\
\text { do } \\
\text { do }\end{array}$ & $\begin{array}{l}7.44 \pm 2.38 \\
8.34 \pm 3.08 \\
7.04 \pm 2.26 \\
7.65 \pm 2.73 \\
7.21 \pm 2.73 \\
7.32 \pm 2.73 \\
7.19 \pm 2.29 \\
7.94 \pm 3.58 \\
6.78 \pm 2.38 \\
6.95 \pm 2.33 \\
6.48 \pm 2.53 \\
7.21 \pm 2.69\end{array}$ & $\begin{array}{l}1-18 \\
2-31 \\
1-16 \\
2-19 \\
2-18 \\
2-20 \\
2-18 \\
1-27 \\
1-16 \\
1-15 \\
1-22 \\
2-22\end{array}$ \\
\hline $\begin{array}{l}\text { Pellicularia } \\
\text { filamentosa }\end{array}$ & $\begin{array}{l}M-1 \\
M-3 \\
M-4 \\
I-64 \\
I-109 \\
I-115\end{array}$ & $\begin{array}{l}\text { Eggplant } \\
\text { White clover } \\
\text { Tomato } \\
\text { Beet } \\
\text { Flax } \\
\text { Locust tree } \\
\text { (Robinia } \\
\quad \text { pseudoacacia) }\end{array}$ & $\begin{array}{l}5.40 \pm 1.84 \\
6.10 \pm 1.69 \\
6.44 \pm 2.21 \\
6.00 \pm 2.35 \\
9.01 \pm 2.67 \\
6.86 \pm 2.44\end{array}$ & $\begin{array}{l}1-15 \\
3-13 \\
2-16 \\
1-21 \\
2-22 \\
2-20\end{array}$ \\
\hline Rhizoctonia oryzae & $\begin{array}{l}10 \\
11 \\
12 \\
13\end{array}$ & $\begin{array}{l}\text { Rice } \\
\text { do } \\
\text { do } \\
\text { do }\end{array}$ & $\begin{array}{l}6.73 \pm 2.61 \\
6.13 \pm 2.83 \\
4.88 \pm 1.45 \\
5.57 \pm 2.14\end{array}$ & $\begin{array}{l}2-24 \\
1-33 \\
1-9 \\
2-16\end{array}$ \\
\hline $\begin{array}{l}\text { Sclerotium } \\
\quad \text { oryzae-sativae }\end{array}$ & $\begin{array}{l}1 \\
\mathrm{~T}-6 \\
\mathrm{~L}-12 \\
\mathrm{~T}-17 \\
\mathrm{~T}-20 \\
\mathrm{~T}-28 \\
\mathrm{~A}-1 \\
\mathrm{~A}-2 \\
\mathrm{~N}-1 \\
\mathrm{~N}-2 \\
\mathrm{~N}-3 \\
\end{array}$ & $\begin{array}{c}\text { Rice } \\
\text { do } \\
\text { do } \\
\text { do } \\
\text { do } \\
\text { do } \\
\text { do } \\
\text { do } \\
\text { do } \\
\text { do } \\
\text { do }\end{array}$ & $\begin{array}{l}2.03 \pm 0.59 \\
2.03 \pm 0.72 \\
1.86 \pm 0.58 \\
1.93 \pm 0.58 \\
2.02 \pm 0.62 \\
1.81 \pm 0.71 \\
2.03 \pm 0.72 \\
2.13 \pm 0.51 \\
1.95 \pm 0.55 \\
2.09 \pm 0.55 \\
1.97 \pm 0.44\end{array}$ & $\begin{array}{l}1-4 \\
1-4 \\
1-4 \\
1-4 \\
1-4 \\
1-4 \\
1-4 \\
1-4 \\
1-4 \\
1-4 \\
1-4\end{array}$ \\
\hline $\begin{array}{l}\text { Sclerotium } \\
\quad \text { hydrophilum }\end{array}$ & $\begin{array}{l}1 \\
2 \\
3\end{array}$ & $\begin{array}{l}\text { Rice } \\
\text { do } \\
\text { do }\end{array}$ & $\begin{array}{l}2.01 \pm 0.34 \\
2.02 \pm 0.29 \\
2.00 \pm 0.46\end{array}$ & $\begin{array}{l}1-5 \\
1-4 \\
1-4\end{array}$ \\
\hline $\begin{array}{l}\text { Sclerotium } \\
\quad \text { fumigatum }\end{array}$ & $\begin{array}{l}1 \\
2 \\
3 \\
4\end{array}$ & $\begin{array}{c}\text { Rice } \\
\text { do } \\
\text { Dayflower } \\
\text { Barnyard } \\
\text { grass }\end{array}$ & $\begin{array}{l}2.10 \pm 0.44 \\
2.03 \pm 0.32 \\
2.17 \pm 0.53 \\
2.06 \pm 0.45\end{array}$ & $\begin{array}{l}1-4 \\
1-4 \\
1=4 \\
1-4\end{array}$ \\
\hline Sclerotium orizicola & & Rice & $5.87 \pm 1.94$ & $1-12$ \\
\hline $\begin{array}{l}\text { Magnaporthe } \\
\text { salvinii } \\
\text { (Conidial state) }\end{array}$ & $\begin{array}{l}1 \\
2\end{array}$ & $\begin{array}{c}\text { Rice } \\
\text { do }\end{array}$ & $\begin{array}{l}1.20 \pm 0.47 \\
1.06 \pm 0.24\end{array}$ & $\begin{array}{l}1-3 \\
1-2\end{array}$ \\
\hline $\begin{array}{l}\text { Curvularia } \\
\text { irregulare }\end{array}$ & $\begin{array}{l}1 \\
2 \\
3\end{array}$ & $\begin{array}{l}\text { Rice } \\
\text { do } \\
\text { do }\end{array}$ & $\begin{array}{l}1.09 \pm 0.24 \\
1.05 \pm 0.24 \\
1.10 \pm 0.30\end{array}$ & $\begin{array}{l}1-3 \\
1-3 \\
1-2\end{array}$ \\
\hline
\end{tabular}

isolate from flax root collected in Hokkaido showed the highest mean value. As stated by Hashioka et al. ${ }^{4)}$ and Ui et al.6), this fungus contains $5 \sim 9$ nuclhi per cell (Fig. 2).

C. Rhizoctonia oryzae: Similar to the results of Hashioka et al.4), all the isolates of rice sheath spot fungus collected in Thailand showed the mean value 5.83 nuclei ranging from 5 to 7 
(Fig. 3).

D. Sclerotium oryzae-sativae: Eleven isolates from Thailand, Laos, Kagoshima and Hokkaido were proved commonly to be binucleate (Fig. 4), irrespective of difference in locality.

E. Sclerotium hydrophilum: In each of isolates from rice plants, more than $90 \%$ of 300 hyphal cells showed to be binucleate (Fig. 5).

F. Sclerotium fumigatum: Irrespective of difference in the source of isolation, i.e. rice, dayflower and barnyard grass, the mode in number of nuclei was found to be 2 , though the range extends from 1 to 4 (Fig. 8).

G. Sclerotium orizicola: Only one isolate from a sheath of rice plant was examined. This fungus showed wide variation in number of nuclei, indicating the mean value of 5.87 (Fig. 6).

H. Magnaporthe salvinii: Observation was made with the conidial state, i.e. Helminthosporium sigmoideum Cav. Mononucleate character was perceived (Fig. 9), though hyphae of this fungus are very fine and the septa are indistinct under microscope.

I. Curvularia irregulare: Although the microscopical observation was similar to the above mentioned fungus, the hyphal cell of this fungus seemed to be uninucleate (Fig. 7).

From present observations, number of nuclei in hyphal cell of Rhizoctonia group was proved to be multinucleate, namely, hyphal cells of Pellicularia sasakii were found to contain 7.3 nuclei in average, Pellicularia filamentosa has 6.6 and Rhizoctonia oryzae has 5.8 nuclei. Those of the different species of Sclerotium were binucleate, except Sclerotium orizicola containing 5.9 nuclei in average, and Magnaporthe salvinii and Curvularia irregulare causing culm rot were mononucleate.

(Received December 18, 1973)

\section{Explanation of Plate}

Nuclei in hyphal cell of the different fungi causing rice sclerotiosis.

Fig. 1. Pellicularia sasakii No. 42 isolated from rice leaf sheath in Thailand.

Fig. 2. Pellicularia filamentosa I-115 from Robinia pseudoacacia in Ibaraki, East Japan.

Fig. 3. Rhizoctonia oryzae No. 13 from rice leaf sheath in Thailand.

Fig. 4. Sclerotium oryzae-sativae A-2 from rice leaf sheath in Kagoshima, Southern Japan.

Fig. 5. Sclerotium hydrophilum No. 3 from rice in India.

Fig. 6. Sclerotium orizicola from rice in Hokkaido, Northern Japan.

Fig. 7. Curvularia irregulare No. 1 from rice in Shizuoka, Middle Japan.

Fig. 8. Sclerotium fumigatum No. 4 from barnyard grass in Aichi, Middle Japan.

Fig. 9. Conidial state (Helminthosporium sigmoideum Cav.) of Magnaporthe salvinii No. 2 from rice in Shizuoka, Middle Japan. 
Plate I

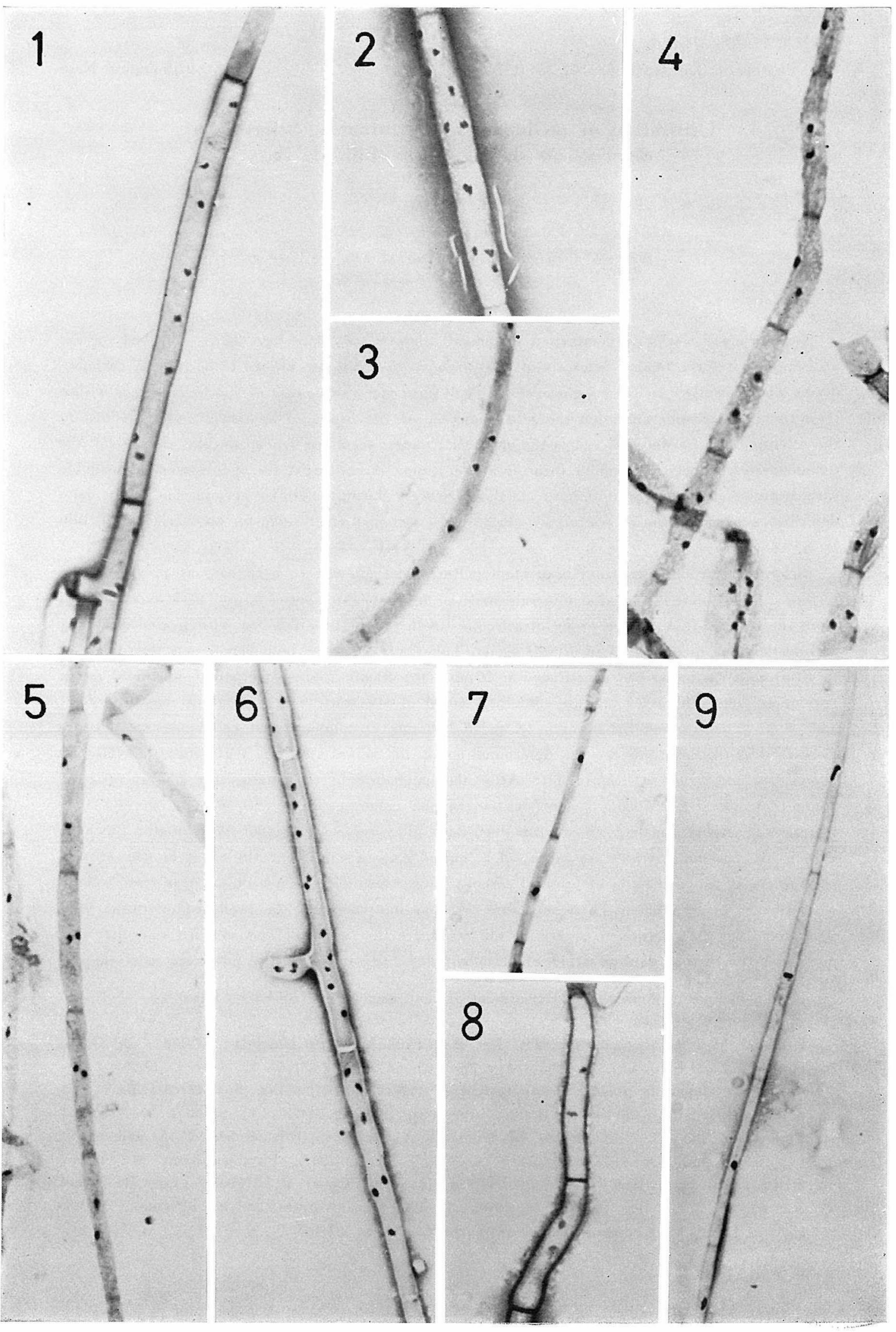

